\title{
Quality Evaluation of Deep Frozen Scraped Coconut
}

\author{
Samarakone H.S.M.D.S.M ${ }^{1}$ and Yalegama L.L.W.C ${ }^{2}$
}

\begin{abstract}
Fresh scraped coconut is highly susceptible to rancidity and microbial spoilage. Consumer acceptability of frozen scraped coconut in terms of chemical, microbiological and sensorial quality for three months of storage period was aimed in this study. Scraped coconut was taken and steam blanched for 5, 10 and 15 minutes using steamer. Half of blanched coconut was mixed with Vitamin $\mathrm{E}$ at 500 $\mathrm{ppm}$. Then it was packed in LLDPE/PET/Al pouches $(200 \mathrm{~g} / \mathrm{pouch})$ and sealed and stored under frozen condition at $-18^{\circ} \mathrm{C}$ using a domestic freezer for 3 months. Control treatment was carried out by keeping the untreated grated coconut at frozen condition. Total plate count (TPC), free fatty acid (FFA) and peroxide values (PV) were measured in two week intervals for 3 months. Sensory properties of frozen coconut samples were tested in monthly intervals. Results revealed that significantly low FFA values in all the treated samples compared to control. The concentrations were below the detectable levels of rancidity ( $1 \%$ as lauric acid). There was no peroxide value detected throughout the study period in both the control and treated samples. It was evident that an inverse relationship occurred between TPC values and blanching time. No differences were seen in sensory attributes in all frozen coconut and were within acceptable range. Application of steam blanching for 15 minutes with/without addition of vitamin $\mathrm{E}$ on fresh scraped coconut has the best advantages to extend the shelf life for minimum of three months to preserve the organoleptic properties at domestic frozen conditions.
\end{abstract}

Keywords: coconut, FFA, TPC, steam blanching, Vitamin E, shelf life, frozen

\footnotetext{
${ }^{1}$ Department of Food Science and Technology, Faculty of Livestock, Fisheries and Nutrition, Wayamba University of Sri Lanka. Makandura, Gonawila, 60170 Sri Lanka.

Email: samarakonedsm@gmail.com

Current Mailing Address: Pahala Nugawela, Maharachchimulla, 60286 Sri Lanka.

${ }^{2}$ Coconut Research Institute, Lunuwila, 61150, Sri Lanka.
} 


\section{Introduction}

Coconut (Cocos nucifera L.) is known as the tree of life, due to its remarkable contribution to human life from all of its kernel, water, husk, shell, wood, leaves, ekels, etc. Mature coconuts play key role in Sri Lankan culinary in the form of milk and grated. Coconut is the principle source of edible oil and fat in the average diet of the majority of Sri Lankan families (Fernando, 1995). Coconut supplies about $22 \%$ of the total calories, which seconds only to rice (Pangahas, 1991).

Normally coconuts must be dehusked, splitted to halves and grated before use in food processing. So these processes are time consuming, unpleasant and extremely disliked. In many cases with high prices of coconut, only a part of the nut is used at each meal, and the rest has to be preserved for later meals, perhaps spread over 2 to 3 days, despite the spoilage which often takes place (Thiagarajan, 1983). So the scraped coconut has high demand in modern society, because it is more convenient and time saving since it is a ready to use product. It can be used as it is, or in milk form. Coconuts are much perishable in nature and difficult to keep longer at room temperature or refrigerated temperature. Therefore, value addition to coconut reduces the wastage of coconut. Furthermore it is convenient to consumers and reduces the transportation costs as it is less bulky.

Coconut is easily susceptible to rancidity (Kumar et al., 1996) and it reduces the oreganoleptic properties with the storage period. Mainly there are three types of rancidity as hydrolytic, oxidative and ketonic rancidity. Around $92 \%$ of coconut fat is saturated fat (Amarasiri, 2006).Due to high content of saturated fatty acids, coconut oil has high resistance to oxidative rancidity. Principal saturated fatty acid in coconut is lauric acid and it accounts for $47.5 \%$ of total fatty acid, but air, light, moisture and pro-oxidants may induce the oxidative rancidity (Shahidi, 2005).

Furthermore, coconut is highly susceptible to hydrolytic rancidity, especially due to bacterial lipases. When food is contaminated by bacteria and subsequent heating of food hydrolyzes triglycerides into free fatty acids. When lauric fats are hydrolyzed lauric acid is produced, which is later converted into sodium salt. That sodium salt gives soapy flavor to the product as a result of hydrolytic rancidity in lauric fats (Hamilton, 2005).

In addition to hydrolytic rancidity, ketonic rancidity could occur in coconut. It is an oxidative type of hydrolytic rancidity resulting aliphatic ketones which cause rancid flavor and odor to coconut. Ketonic rancidity is a result of fatty acid degradation of moulds (Kellard et al., 1985).

In order to avoid rancidity problem and to increase the shelf life, researches were carried out to develop the preservation method for scraped coconut under various storage conditions in the aid of several food additives. As many food additives were used in present preservation methods; development of new methods using minimum amount of food additives, is more advantageous due to current trend of using minimally processed foods.

The effects due to pre treatments, storage conditions and food additives on shelf life and quality attributes can be varied due to the combined effect. Therefore the purpose of the study was to develop a method to extend the shelf life of scraped coconut by combining the antioxidant property of Vitamin E together with the effects of thermal pre treatment and frozen storage conditions.

\section{Materials and methods}

\section{Raw Materials}

Coconuts were obtained from the Bandirippuwa estate of Coconut Research Institute, Sri Lanka. CRIC 60 was the variety of coconut. 11 months old coconuts were harvested and kept for 3 weeks for seasoning. Seasoned nuts of the same pick were used in this study. All the chemicals used in this research were of analytical grade and the additives were of food grade.

\section{Sample Preparation}

Mature coconuts were dehusked and soaked in $2 \%$ chlorine bleach solution for 15 
minutes. Coconut kernel without brown testa was grated to obtain scraped coconut using an electric scraper (ODIRIS, Sri Lanka).

Scraped coconut was taken and steam blanched for 5, 10 and 15 minutes using steamer. Half of blanched coconut was mixed with Vitamin $\mathrm{E}$ at the level of $500 \mathrm{ppm}$, because antioxidant activity of Vitamin E usually occurs at concentrations above 500ppm (Eitenmiller and Lee, 2005). Then it was packed in LLDPE/PET/Al pouches (200 g/pouch) and sealed and stored under frozen condition at $18^{\circ} \mathrm{C}$ in a freezer (LG, model GR-U292SLC, Korea) for 3 months. Control treatment was carried out by keeping the untreated (unblanched and without Vitamin E) grated coconut at frozen conditions.

\section{Microbiological Analysis}

Total plate counts (TPC) were determined for each sample at biweekly intervals for three months using pour plate method described in SLS - 516, part-1, 1991.

\section{Chemical Analysis}

All samples were analyzed for free fatty acid (FFA) content and peroxide value (PV) at biweekly intervals for three months. FFA content and PV were determined as described in Pearson (1973).

\section{Sensory Evaluation}

Organoleptic qualities of coconut sambol prepared with frozen coconut samples were evaluated at monthly intervals for a period of three months using 5 point hedonic scale. Taste, color, flavor, texture, appearance and overall acceptability were used as sensory attributes. Twenty five semi trained panelists were used for this study.

\section{Statistical Analysis}

Data were analyzed by analysis of variance using PC-SAS (version 6.12; SAS Institute Inc., Cary, NC, USA), GLM with treatment, time and treatment $\times$ time as main factors. Significant differences among treatment means were analyzed by least significant difference test. Sensory data were analyzed by freedman test using Minitab (Version 15, LEAD Technologies, INC, USA). The level of significance was set as at $\mathrm{P}<0.05$.

\section{Results and Discussion}

\section{Microbiological Analysis}

There was a main effect of treatments $(\mathrm{P}<0.0001)$, time $(\mathrm{P}<0.0001)$ and, treatment-time interaction $(\mathrm{P}<0.0001)$ on microbial values. Variations of microbial count of different treatments are given in Table 1.

All treated samples were significantly $(\mathrm{P}<$ 0.05) different from control sample. Control sample had shown highest TPC values which rapidly increased with the time. According to the results of the study, TPC values were significantly $(\mathrm{P}<0.05)$ reduced with increasing blanching time. The TPC values were reduced in relation to the blanching time period $(5 \mathrm{~min}>10$ $\min >15 \mathrm{~min})$. The lowest TPC values $\left(<1 \times 10^{1}\right.$ $\mathrm{cfu} / \mathrm{g}$ ) were recorded for $15 \mathrm{~min}$ blanched sample. It was not changed with storage time. These observations may suggest that steam blanching for $15 \mathrm{~min}$ has a capability of destructing virtually all microorganisms present in the food.

Evans (2008) reported that microbial deterioration is not a problem in frozen foods because they are stored at temperatures below the lower limits of microbial growth (approximately $-10^{\circ} \mathrm{C}$ ). Storage temperatures below $-10^{\circ} \mathrm{C}$ inhibit the bacterial growth, whereas yeasts and molds cannot multiply below $-12^{\circ} \mathrm{C}$ and $-18^{\circ} \mathrm{C}$. Due to the temperature fluctuations during storage may reduce the effect of freezing on microbial deterioration. Although control and $5 \mathrm{~min}$ blanched samples had relatively higher amount of TPC which might show an affinity to increase the TPC with the time. Therefore $10 \mathrm{~min}$ and $15 \mathrm{~min}$ blanched samples were better in terms of long shelf life.

\section{Free Fatty Acid (FFA) Value}

There was a main effect of treatments $(\mathrm{P}<0.0001)$, time $(\mathrm{P}<0.0001)$ and, treatment-time interaction $(\mathrm{P}<0.0001)$ on FFA. The high content of free fatty acid in non treated control sample was higher than treated samples (Figure 1). 
Table 1. Total plate counts values of scraped coconut stored at $-18^{\circ} \mathrm{C}$

\begin{tabular}{lllll|lll}
\hline & & \multicolumn{3}{c|}{ Without Vitamin E } & \multicolumn{3}{c}{ With Vitamin E } \\
\cline { 3 - 7 } Time (Wks) & Control $^{\mathrm{a}}$ & $5 \mathrm{~min}^{\mathrm{b}}$ & $10 \mathrm{~min}^{\mathrm{d}}$ & $15 \mathrm{~min}^{\mathrm{e}}$ & $5 \mathrm{~min}^{\mathrm{c}}$ & $10 \mathrm{~min}^{\text {ed }}$ & $15 \mathrm{~min}^{\mathrm{e}}$ \\
\hline 0 & $1.7 \times 10^{3}$ & $<1 \times 10^{1}$ & $<1 \times 10^{1}$ & $<1 \times 10^{1}$ & $<1 \times 10^{1}$ & $<1 \times 10^{1}$ & $<1 \times 10^{1}$ \\
2 & $1.8 \times 10^{3}$ & $<1 \times 10^{1}$ & $<1 \times 10^{1}$ & $<1 \times 10^{1}$ & $<1 \times 10^{1}$ & $<1 \times 10^{1}$ & $<1 \times 10^{1}$ \\
4 & $2.0 \times 10^{3}$ & $2.5 \times 10^{2}$ & $2.5 \times 10^{1}$ & $<1 \times 10^{1}$ & $1.8 \times 10^{2}$ & $1.7 \times 10^{1}$ & $<1 \times 10^{1}$ \\
6 & $2.0 \times 10^{3}$ & $9.3 \times 10^{2}$ & $4.5 \times 10^{1}$ & $<1 \times 10^{1}$ & $6.0 \times 10^{2}$ & $3.0 \times 10^{1}$ & $<1 \times 10^{1}$ \\
8 & $6.5 \times 10^{3}$ & $1.9 \times 10^{3}$ & $8.0 \times 10^{1}$ & $<1 \times 10^{1}$ & $9.3 \times 10^{2}$ & $5.1 \times 10^{1}$ & $<1 \times 10^{1}$ \\
10 & $9.6 \times 10^{3}$ & $2.8 \times 10^{3}$ & $2.1 \times 10^{1}$ & $<1 \times 10^{1}$ & $1.0 \times 10^{3}$ & $6.5 \times 10^{1}$ & $<1 \times 10^{1}$ \\
\hline
\end{tabular}

Data were expressed in $\mathrm{cfu} / \mathrm{g}$

a, b, c, d, e lacking a common superscript letter differ significantly $(\mathrm{P}<0.05)$.

Table 2. Effect of storage period on sensory ratings of frozen scraped coconut

\begin{tabular}{lllllll}
\hline \multirow{2}{*}{ Treatment } & \multicolumn{7}{c}{\begin{tabular}{c} 
P values \\
\cline { 2 - 6 }
\end{tabular}} & $\begin{array}{l}\text { Time } \\
\text { (months) }\end{array}$ & Odor & Taste & Color & Texture & $\begin{array}{l}\text { Overall } \\
\text { acceptability }\end{array}$ \\
\hline Blanched & 1 & 0.427 & 0.533 & 0.113 & 0.432 & 0.546 \\
& 2 & 0.527 & 0.459 & 0.629 & 0.204 & 0.425 \\
& $3^{*}$ & 0.995 & 0.667 & 0.420 & 0.532 & 0.544 \\
Blanched with & 1 & 0.250 & 0.705 & 0.159 & 0.304 & 0.614 \\
Vitamin E & 2 & 0.839 & 0.486 & 0.345 & 0.438 & 0.234 \\
& $3^{*}$ & 0.543 & 0.673 & 0.329 & 0.673 & 0.456 \\
\hline
\end{tabular}

*At 3 months blanched samples were compared with fresh coconut instead of control sample 
Figure 1. Effect of different blanching treatments and Vitamin $E$ addition on the FFA content of frozen scraped coconut
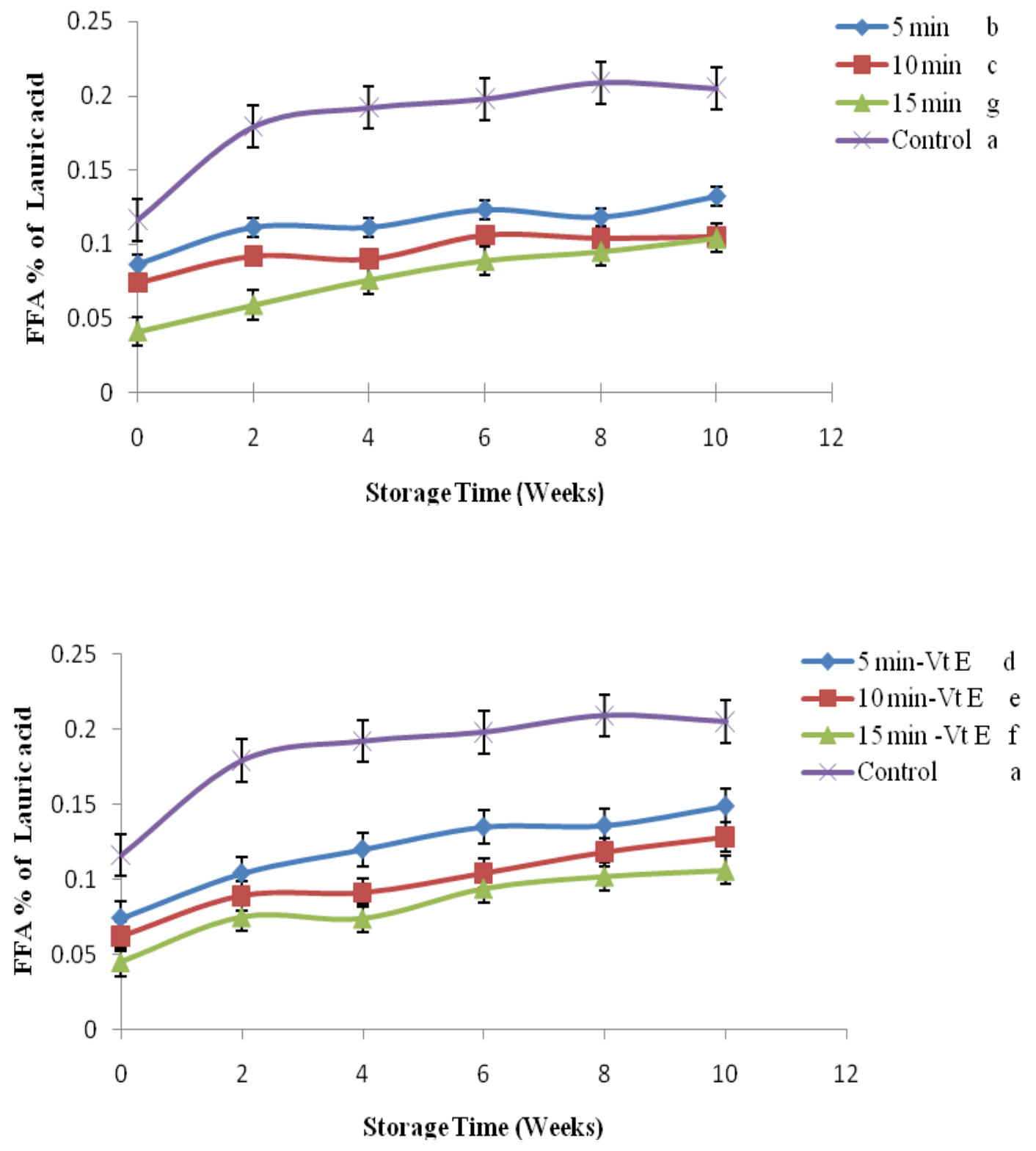
Although FFA values increased with the time, they were not exceeded above the detectable critical limit of $1 \%$ as lauric acid (Pearson, 1973).

FFA values of blanched samples were less than the control sample probably due to inactivation of lipase during storage conditions $\left(-18^{\circ} \mathrm{C}\right)$. The results were similar to those reported by Waisundara et al. (2007). Further lipases can be inactivated due to the high blanching temperature because lipase enzymes can be denatured during moderate heat treatments (Waisundara et al., 2007, Fennema, 1997). According to previously mentioned results of microbiological analysis, microbial load was reduced when increasing the blanching time. It might cause less production of microbial lipase and subsequent FFA formation. The high amount of FFA, during storage had been shown an inverse relationship with blanching time. So both 15 minute steam blanched samples had relatively less FFA content than in other steam blanched samples. But due to the temperature fluctuations of domestic freezers FFA can be significantly affected.

\section{Peroxide Value}

There was no peroxide detected throughout the period of 12 weeks in both control and treated samples. Arachchi et al. (2007) also reported that there was no peroxide value of refrigerated scraped coconut which was blanched for 90 seconds.

Normally coconut has strong resistance to oxidative rancidity due to the presence of high amount of saturated fatty acids. But it can undergo oxidative rancidity due to the presence of prooxidants such as light, oxygen (Shahidi, 2005). Due to the addition of vitamin $\mathrm{E}$, oxidative rancidity can be greatly minimized because of its unique antioxidant property. In this study, samples were packed in LLDPE/PET/Al pouches. Aluminium is a total barrier to moisture, oxygen and light. PET acts as good moisture and oxygen barrier (Marsh and Bugusu, 2007). Therefore packaging of samples can minimize the exposure to light and oxygen and by that reduces the potential of the oxidative rancidity. Therefore oxidative byproducts were not detected and peroxide values were not observed.

\section{Sensory Evaluation}

No significant differences of sensory attributes could be seen among all treatments throughout the three months of storage period (Table 2). Odor and taste may not change due to low free fatty acid content and peroxide value. Volatile off odors and flavors of coconut samples were remained at acceptable range. No differences were seen in color and texture changes, it may be below the detectable limit.

\section{Conclusions}

The level of FFA values and microbial count were increased in control sample than blanched samples throughout the experimental period. There was no peroxide value detected throughout the study period in both control and treated samples. FFA of all samples was remaining under critical limit of $1 \%$ as Lauric acid. All samples had less TPC values. There was no significant difference between treated and fresh samples in terms of sensory attributes up to three months of frozen storage. Application of steam blanching and addition of vitamin $E$ on fresh scraped coconut extends the shelf life for minimum of three months at domestic frozen conditions.

Further studies must be carried out to investigate the nutrition loss during blanching and frozen storage. Ascorbate level determination is much suitable due to ease of measurement and it is present at significant level in coconut. Further, cost-benefit analysis must be carried out to evaluate the cost of product.

\section{Acknowledgement}

The authors wish to acknowledge to $\mathrm{Mr}$. DP Kumaratunge, Research Officer, Division of Biometry, Coconut Research Institute, Lunuwila for the statistical analysis and to all the staff members of Coconut Processing Research Division, Coconut Research Institute, Lunuwila and Department of Food Science and Technology, Wayamba University of Sri Lanka. Special thanks to Mr. KDPP Gunathilake, Senior Lecturer, Department of Food Science and 
Technology, Wayamba University of Sri Lanka for critically going through the manuscript.

\section{References}

Amarasiri, W.A.D.L. 2006. Coconut fats. Ceylon Medical Journal. 51: 47-51

Arachchi, L.A.C.N.L., Gunathilake, K.D.P.P. and Yalegama Y.M.L.C. 2007. Storage Studies on Frozen Coconut Based Products. Annual Report 2007. Coconut Research Institute. Sri Lanka. p. 190-193.

Eitenmiller, R.R and Lee, J. 2005. Vitamin E: Food Chemistry, Composition and Analysis. $1^{\text {st }}$ Ed. CRC Press, USA.105 pp.

Evans, J.A. 2008. Frozen Food Science and Technology. $1^{\text {st }}$ Ed. Blackwell Publishing Ltd,UK. 234 pp.

Fennema, O.R.1996. Food Chemistry. $3^{\text {rd }}$ Ed. Marcel Dekker Inc., USA. 402 pp.

Fernando, H. 1995. Coconut Industry in Sri Lanka. Towards Optimum Development. in Proc. Coconut Research Conference. 1: 7- 10.

Hamilton, D. 2005. Off flavors in food. <http://www.britanniafood.com/common/ invite_17.htm> accessed in $6^{\text {th }}$ June 2011.

Kellard, B., Busfield, D.M. and Kinderlerer, J.L.1985.Volatile off-flavour compounds in desiccated coconut. J. Sci. of Food and Agric. 36:415-420

Kumar, R., Manimegalani, G. and Neelakanthi, S. 1996. Techniques to preserve the freshness of the coconut kernels. Indian Food Packer. 50:32-40

Marsh, K. and Bugusu, B. 2007. Food Packaging Roles, Materials, and Environmental effects. J. Food Sci. 72:39-55
Pangahas, B.B .1991. Small scale processing of coconut products: Proceedings of the XXVIII COCOTECH Meeting. Asian and Pacific Coconut Community, Indonesia. 242-245 pp.

Pearson, D. 1973. Laboratory Techniques in Food Analysis. $1^{\text {st }}$ Ed. Butterworth and Company Publishers Ltd, UK. 124-128 pp.

Shahidi,F .2005. Bailey's Industrial Oil and Fat Products. $6^{\text {th }}$ Ed. John Wiley \& Sons, Inc., USA. 142-143 pp.

Thiagarajan, B. 1983. The processing of fresh coconuts. Indian Coconut Journal. 18:1219

Waisundara, V. Y., Perera, C. O., and Barlow, P. J. 2007. Effect of different pre-treatments of fresh coconut kernels on some of the quality attributes of the coconut milk extracted. Food chem. 101: 771-777 